CZASOPISMO INŻYNIERII LĄDOWEJ, ŚRODOWISKA I ARCHITEKTURY JOURNAL OF CIVIL ENGINEERING, ENVIRONMENT AND ARCHITECTURE

JCEEA, t. XXXIII, z. 63 (2/II/16), kwiecień-czerwiec 2016, s. 445-455

Agnieszka STEC ${ }^{1}$

\title{
MODEL OPTYMALIZACYJNY RETENCYJNEGO ZBIORNIKA RUROWEGO
}

\begin{abstract}
W publikacji przedstawiono sformułowany model optymalizacyjny zbiornika rurowego, który jest kontynuacją badań opisanych w artykule [16]. Model kosztowy Life Cycle Cost $(L C C)$ zbiornika rurowego został przekształcony w model optymalizacyjny, w którym wyznaczono funkcję celu jako minimum kosztów LCC. Zastosowanie tego kryterium w procesie podejmowania decyzji inwestycyjnych umożliwia dokonanie poprawnego pod względem finansowym wyboru, gdyż metodologia $L C C$ pozwala na uwzględnienie nie tylko początkowych nakładów inwestycyjnych, ale również kosztów eksploatacyjnych ponoszonych w całym okresie funkcjonowania danego obiektu. Przedstawiony model optymalizacyjny został następnie zaimplementowany w języku programowania AMPL (A Mathematical Programming Language). W sformułowanym modelu wyznaczono zmienne decyzyjne, którymi są poszukiwane wartości parametrów geometrycznych zbiornika, takie jak: długość i średnica zbiornika oraz zagłębienie kanału odpływowego ze zbiornika. Określono także ograniczenia modelu optymalizacyjnego zbiornika rurowego. Pierwsze z nich wynika z wymaganej pojemności retencyjnej zbiornika obliczonej na etapie wyznaczania danych wejściowych, na którą jest projektowany zbiornik. Następne ograniczenia dotyczą powierzchni terenu, która dostępna jest pod budowę zbiornika oraz ograniczenie określające minimalne dopuszczalne zagłębienie kanału odpływowego ze zbiornika. Natomiast parametry modelu optymalizacyjnego stanowią zbiór danych, które zostały użyte do zapisu funkcji celu i których wartości są znane. Należą do nich przede wszystkim ceny poszczególnych materiałów i robót oraz podstawowe wymiary elementów konstrukcyjnych zbiornika.
\end{abstract}

Słowa kluczowe: zbiorniki rurowe, kanalizacyjne zbiorniki retencyjne, Life Cycle Cost, optymalizacja

\section{Wprowadzenie}

Każde zadanie inżynierskie jest spowodowane określoną potrzebą społeczną, a efektem jego rozwiązania jest osiągnięcie założonego celu. Zasada racjonalnego gospodarowania zakłada, że przy danym nakładzie środków możliwe jest osiągnięcie maksimum realizacji celu lub cel można osiągnąć przy minimal-

\footnotetext{
${ }^{1}$ Agnieszka Stec, Politechnika Rzeszowska, Wydział Budownictwa, Inżynierii Środowiska i Architektury, 35-959 Rzeszów, Al. Powstańców Warszawy 12, e-mail: stec_aga@prz.edu.pl, tel. 178651071
} 
nym nakładzie środków. Wykorzystanie środków według zasady racjonalnego gospodarowania nazywa się sposobem optymalnym [4].

Zadanie takie można zapisać w sposób matematyczny, który pozwala na pełniejsze zrozumienie procesów i zjawisk występujących w rzeczywistości. Według Gutenbauma zadaniem modeli, które stosowane są w nauce jest stworzenie uproszczonej formy zapisu odwzorowującego rzeczywisty badany obiekt [8]. Model matematyczny zatem opisuje nieskończoną liczbę pokrewnych problemów optymalizacji, a w chwili, gdy zostaną już określone wartości poszczególnych danych, to wówczas model reprezentował będzie konkretny problem lub stanie się przykładem modelu, który może zostać rozwiązany. Inny zestaw wartości parametrów generuje odmienny wariant modelu.

Podstawowym celem optymalizacji w rozumieniu matematycznym jest znalezienie punktów ekstremalnych funkcji celu $f(x)$, gdzie $x$ jest zmienną decyzyjną, która może przyjmować wartości ze zbioru dopuszczalnego.

Zadania optymalizacji można podzielić według kilku podstawowych kryteriów [4]:

a) ze względu na rodzaj funkcji celu i ograniczenia:

- zadania programowania liniowego, w których funkcja celu i ograniczenia są liniowe,

- zadania programowania nieliniowego,

b) ze względu na typ zmiennych decyzyjnych:

- zadania całkowitoliczbowe,

- zadania binarne,

- zadania mieszane,

c) ze względu na liczbę funkcji celu:

- zadania jednokryterialne,

- zadania wielokryterialne.

Ponadto można wyróżnić optymalizację statyczną i dynamiczną. Pierwsza z nich zajmuje się poszukiwaniem rozwiązania optymalnego, którym jest punkt wyznaczający najlepszą funkcję celu. W zależności od rodzaju sformułowanego zadania funkcja ta może przyjmować wartość najmniejszą lub największą. Jeżeli poszukiwanie tej wartości odbywa się w ograniczonym obszarze, to rozwiązaniem jest ekstremum funkcji lokalne, natomiast ekstremum globalne poszukiwane jest w całej przestrzeni argumentów. Jednak nie zawsze możliwe jest znalezienie ekstremum globalnego, gdyż większość dostępnych algorytmów umożliwia znalezienie jedynie ekstremum lokalnego. W takim przypadku skuteczność tego procesu uzależniona jest od ustawienia właściwego punktu startowego.

Optymalizacja znajduje zastosowanie w wielu dziedzinach gospodarki, m.in. w projektowaniu produktów i procesie ich produkcji, w ekonomii i zarządzaniu firmami, w projektowaniu i budowie maszyn, samochodów, samolotów oraz obiektów budowlanych. 
Optymalizacja systemów kanalizacyjnych jest zagadnieniem bardzo złożonym, gdyż wymaga uwzględnienia szeregu aspektów konstrukcyjnych, hydraulicznych oraz środowiskowych [18]. Odmienne wymagania stawiane poszczególnym obiektom współdziałającym z siecią kanalizacyjną mogą decydować również o przyjęciu różnych funkcji celu dla każdego z tych elementów. W rezultacie rozwiązanie zadania optymalizacyjnego całego systemu kanalizacyjnego sprowadza się do sformułowania cząstkowych modeli optymalizacyjnych jego poszczególnych składowych [6].

Dotychczas optymalizacja systemów kanalizacyjnych dotyczyła głównie projektowania i budowy samych sieci, bez uwzględniania w niej obiektów retencyjnych. Wyniki badań optymalizacyjnych przeprowadzonych na wybranych modelach układów hydraulicznych zbiorników retencyjnych zlokalizowanych w systemie kanalizacji ogólnospławnej przedstawiono w pracy [17]. Natomiast pierwsze prace związane $\mathrm{z}$ procesem optymalizacji systemów odprowadzania ścieków pojawiły się już w latach 60-tych XX wieku [9, 12]. W kolejnych latach podjęto badania, których celem było opracowanie ulepszonych metod projektowania sieci kanalizacyjnych [5, 13-15, 19].

Dopiero rozwój techniki komputerowej umożliwił zastosowanie zaawansowanych metod optymalizacyjnych, m.in. algorytmów genetycznych, w poszukiwaniu optymalnych rozwiązań problemów dotyczących projektowania systemów kanalizacyjnych [2, 3].

W artykule opisano model optymalizacyjny zbiornika rurowego, który jest zadaniem optymalizacji jednokryterialnej. Funkcja celu ma postać skalarną i dąży do minimalizacji kosztów Life Cycle Cost $(L C C)$ budowy oraz eksploatacji analizowanego zbiornika retencyjnego. Analiza kosztów LCC pozwala uwzględnić początkowe nakłady inwestycyjne oraz koszty wynikające z użytkowania danego obiektu w całym okresie jego funkcjonowania [1]. W pierwszej kolejności przygotowywana jest struktura kosztów, według następujących kategorii: nakłady inwestycyjne, koszty eksploatacyjne oraz koszty przeznaczone na likwidację danego produktu, instalacji czy obiektu budowlanego. Następnie, na podstawie szczegółowych modeli nakładów inwestycyjnych i kosztów eksploatacyjnych, opracowywany jest całościowy model $L C C$. Model ten opisuje rzeczywistość poprzez matematyczny zapis sumy kosztów związanych z badanym problemem. W modelu $L C C$ zbiornika rurowego, który szczegółowo przedstawiono w publikacji [16], nie wzięto pod uwagę kosztów jego likwidacji. Wynika to z bardzo długiego okresu eksploatacji, jaki przyjmowany jest przy projektowaniu systemów kanalizacyjnych i obiektów z nimi współdziałających. Zatem, całkowite koszty LCC można wyznaczyć ze wzoru (1) [11].

$$
L C C=K_{I}+\sum_{t=1}^{T} K_{E}\left(\frac{1}{(1+r)^{t}}\right)
$$


gdzie: $K_{I}$ - całkowite nakłady inwestycyjne budowy rurowego zbiornika retencyjnego, zł;

$K_{E}$ - roczne koszty eksploatacyjne wynikające z funkcjonowania rurowego zbiornika retencyjnego, zł;

$T$ - okres eksploatacji zbiornika retencyjnego, lata;

$t$ - kolejny rok eksploatacji zbiornika, -;

$r$ - stopa dyskontowa, -.

\section{Model optymalizacyjny zbiornika rurowego}

Opracowany i przedstawiony w publikacji [16] model kosztowy LCC został przetransformowany $\mathrm{w}$ model optymalizacyjny $\mathrm{w}$ celu znalezienia minimum wyznaczonej funkcji celu, którą ogólnie można zapisać równaniem (2).

$$
f(x)=L C C \rightarrow \min
$$

$\mathrm{W}$ modelu tym wyznaczono, zgodnie $\mathrm{z}$ rysunkiem 1 , zmienne decyzyjne, którymi są poszukiwane wartości parametrów geometrycznych zbiornika, takie jak: długość i średnica zbiornika oraz zagłębienie kanału odpływowego ze zbiornika.

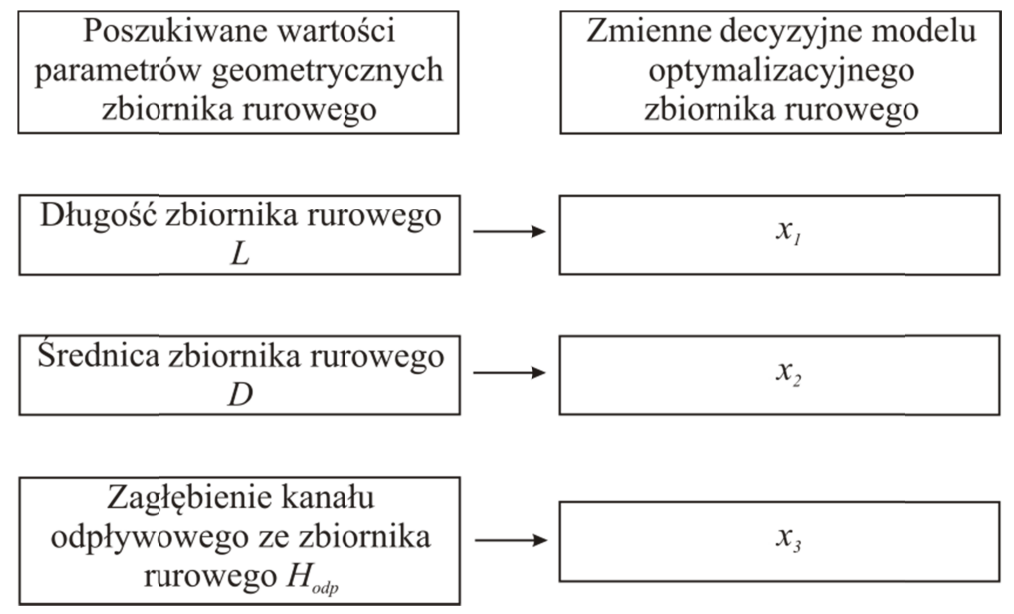

Rys. 1. Zmienne decyzyjne modelu optymalizacyjnego zbiornika rurowego

Fig. 1. Decision variables in the optimization model of the pipe tank

Biorąc pod uwagę wyznaczone zmienne decyzyjne funkcja celu w modelu optymalizacyjnym zbiornika przyjmie postać zależności (3). 


$$
\begin{aligned}
& f(x)=\min \left\{C_{z i e m} \cdot\left(x_{1}+2 s\right) \cdot\left(x_{2}+2 s\right)+C_{o d w} \cdot I_{\text {godz }}+\right. \\
& +C_{w b} \cdot 2\left(x_{2}+2 s\right)+2\left(x_{1}+2 s\right) \cdot\left(x_{3}+D_{o d p}+G_{\text {pias }}+a\right)+ \\
& +C_{w y} \cdot 2\left(x_{2}+2 s\right)+2\left(x_{1}+2 s\right) \cdot\left(x_{3}+D_{o d p}+G_{p i a s}+a\right)+ \\
& +C_{w d} \cdot\left(x_{2}+2 s\right) \cdot\left(x_{1}+2 s\right) \cdot\left(x_{3}+D_{o d p}+G_{p i a s}\right)+C_{p i a s} \cdot\left(x_{2}+2 s\right) \cdot x_{1} \cdot G_{p i a s}+ \\
& +C_{z a s} \cdot\left[\left(x_{2}+2 s\right) \cdot\left(x_{1}+2 s\right) \cdot\left(x_{3}+D_{o d p}+G_{p i a s}\right)-\right. \\
& \left.+\left(x_{1} \cdot \frac{\pi x_{2}^{2}}{4}+x_{1} \cdot\left(x_{2}+2 s\right) \cdot G_{p i a s}\right)\right]+C_{m z} \cdot x_{1}+C_{r z} \cdot x_{1}+C_{s t} \cdot I_{s t}+ \\
& +C_{k l} \cdot I_{k l}+C_{r e g} \cdot I_{r e g}+C_{u r z p t} \cdot I_{u r z p t}+ \\
& +C_{p r z o d p} \cdot L_{p r z o d p}+C_{w p r z o d p} \cdot L_{p r z o d p} \cdot D_{p r z o d p} \cdot\left(x_{3} \cdot D_{p r z o d p}\right)+ \\
& \left.+\sum_{i=1}^{n}\left[C_{p r z i} \cdot L_{p r z i}+C_{w p r z i} \cdot D_{p r z i} \cdot\left(H_{p r z i}+D_{p r z i}\right)\right]+\sum_{t=1}^{T} C_{c z} \cdot x_{1} \frac{1}{(1+r)^{t}}\right\}
\end{aligned}
$$

Określono także ograniczenia modelu optymalizacyjnego zbiornika rurowego. Pierwsze $\mathrm{z}$ nich wynika $\mathrm{z}$ wymaganej pojemności retencyjnej zbiornika obliczonej na etapie wyznaczania danych wejściowych, na którą jest projektowany zbiornik (4). Następne ograniczenia dotyczą powierzchni terenu, która dostępna jest pod budowę zbiornika (5), (6) i (7). Sformułowano również ograniczenie modelu optymalizacyjnego, określające minimalne dopuszczalne zagłębienie kanału odpływowego ze zbiornika (8).

$$
\begin{aligned}
& \left(x_{1}+2 s\right) \cdot\left(x_{2}+2 s\right) \leq F_{\text {ter }} \\
& x_{1} \cdot \frac{\pi x_{2}^{2}}{4}=V_{z b} \\
& x_{1}+2 s \leq L_{d z} \\
& x_{2}+2 s \leq B_{d z} \\
& x_{3} \geq\left(H_{d o p}+x_{2}\right)-D_{p r z o d p}
\end{aligned}
$$

gdzie: $F_{t e r}$ - dostępna powierzchnia terenu pod realizację inwestycji związanej $\mathrm{z}$ budową zbiornika retencyjnego, $\mathrm{m}^{2}$; $V_{z b}$ - wymagana pojemność retencyjnego zbiornika rurowego, $\mathrm{m}^{3}$; $L_{d z}$ - długość działki przeznaczonej pod realizację inwestycji związanej $\mathrm{z}$ budową zbiornika retencyjnego, $\mathrm{m}$;

$B_{d z}-$ szerokość działki przeznaczonej pod realizację inwestycji związanej $\mathrm{z}$ budową zbiornika retencyjnego, $\mathrm{m}$. 
W związku z tym, że parametry geometryczne zbiornika retencyjnego nie mogą przyjmować wartości ujemnych ani równych 0 sformułowano także dolne ograniczenia modelu optymalizacyjnego, które zapisano formułami (9), (10) i (11).

$$
\begin{aligned}
& x_{1}>0 \\
& x_{2}>0 \\
& x_{3}>0
\end{aligned}
$$

Parametry modelu optymalizacyjnego stanowią zbiór danych, które zostały użyte do zapisu funkcji celu i których wartości są znane. Należą do nich przede wszystkim ceny poszczególnych materiałów i robót oraz podstawowe wymiary elementów konstrukcyjnych zbiornika. W modelu optymalizacyjnym zbiornika rurowego parametrami tymi są:

- $C_{z i e m}$ - cena jednostkowa zakupu terenu pod realizację inwestycji, $\mathrm{z} / \mathrm{m}^{2}$;

- $s$ - szerokość pasa terenu wokół zbiornika retencyjnego wynikający z uwarunkowań technicznych wykonywania jego konstrukcji, m;

- $C_{o d w}$ - cena jednostkowa odpompowywania wody gruntowej $\mathrm{z}$ wykopu, zł/godz.;

- $I_{\text {godz }}$ - liczba godzin pompowania wody gruntowej z wykopu, godz.;

- $C_{w b}$ - cena jednostkowa wbijania ścianek szczelnych w grunt, zł/m;

- $C_{w y}$ - cena jednostkowa usuwania ścianek szczelnych z gruntu, zł/m;

- $D_{\text {odp }}$ - średnica kanału odpływowego ze zbiornika, m;

- $G_{\text {pias }}$ - grubość warstwy podsypki piaskowej pod dnem zbiornika retencyjnego, m;

- $a$ - naddatek określający głębokość wbicia ścianek szczelnych poniżej warstwy podsypki piaskowej pod dnem zbiornika retencyjnego, m;

- $C_{w d}$ - cena jednostkowa wydobycia gruntu, $\mathrm{z} \mathrm{t} / \mathrm{m}^{3}$;

- $C_{\text {pias }}$ - cena jednostkowa piasku, $\mathrm{z} \mathrm{z} / \mathrm{m}^{3}$;

- $C_{z a s}$ - cena jednostkowa zasypania wykopów, $\mathrm{z} / \mathrm{m}^{3}$;

- $C_{m z}$ - cena jednostkowa zakupu zbiornika rurowego, zł $/ \mathrm{mb}$.;

- $C_{r z}$ - cena jednostkowa robocizny przy wykonaniu konstrukcji zbiornika, $\mathrm{zt} / \mathrm{mb}$;

- $C_{s t}$ - cena jednostkowa zakupu studzienki kanalizacyjnej, zt/szt.;

- $I_{s t}$ - liczba studzienek, szt.;

- $C_{k l}$ - cena jednostkowa zwrotnych zaworów klapowych zainstalowanych w zbiorniku retencyjnym, zł/szt.;

- $I_{k l}$ - liczba zwrotnych zaworów klapowych zainstalowanych w zbiorniku retencyjnym, szt.;

- $C_{r e g}$ - cena jednostkowa regulatorów przepływu zainstalowanych w zbiorniku retencyjnym, zł/szt.; 
- $I_{\text {reg }}$ - liczba regulatorów przepływu zainstalowanych w zbiorniku retencyjnym, szt.;

- $C_{\text {urzpt }}$ - cena jednostkowa urządzenia płuczącego zainstalowanego w zbiorniku retencyjnym, zł/szt.;

- $I_{u r z p t}$ - liczba urządzeń płuczących zainstalowanych w zbiorniku retencyjnym, szt.;

- $C_{p r z i}$ - cena jednostkowa zakupu $i$-tego odcinka przewodu sieci kanalizacyjnej zlokalizowanej poniżej zbiornika, zł/mb.;

- $L_{p r z i}$ - długość i-tego odcinka przewodu sieci kanalizacyjnej zlokalizowanej poniżej zbiornika, m;

- $C_{w p r z i}$ - cena jednostkowa wykonania wykopu i ułożenia $i$-tego odcinka przewodu sieci kanalizacyjnej zlokalizowanej poniżej zbiornika, $\mathrm{zt} / \mathrm{m}^{3}$;

- $D_{p r z i}$ - średnica $i$-tego odcinka przewodu sieci kanalizacyjnej zlokalizowanej poniżej zbiornika, m;

- $H_{\text {przi }}$ - zagłębienie $i$-tego odcinka przewodu sieci kanalizacyjnej zlokalizowanej poniżej zbiornika, m;

- $C_{c z}$ - cena jednostkowa usunięcia osadów z dna zbiornika rurowego, zł/mb.;

- $T$ - okres eksploatacji zbiornika retencyjnego, lata;

- $t$ - kolejny rok eksploatacji zbiornika, -;

- $r$-stopa dyskontowa, -.

\section{Język modelowania AMPL}

Zapisany $\mathrm{w}$ formie matematycznej model optymalizacyjny retencyjnego zbiornika rurowego został zaimplementowany w języku modelowania A Mathematical Programming Language (AMPL). Język ten jest profesjonalnym środowiskiem modelowania, które pozwala rozwiązywać, zarówno zadania liniowe, jak i nieliniowe. Przystosowany jest do wprowadzania zadań w formie zbliżonej do naturalnego zapisu matematycznego, co ułatwia ich modelowanie i analizowanie.

Język modelowania AMPL został stworzony w Stanach Zjednoczonych. Jest złożonym, a tym samym zaawansowanym i efektywnym narzędziem wykorzystywanym w badaniach optymalizacyjnych [7]. System AMPL zbudowany jest $\mathrm{z}$ kilku podstawowych elementów, takich jak: algebraiczny język modelowania, solvery i interaktywne środowisko poleceń. W programie tym plik modelu może być uruchamiany bez odwoływania się do innych plików, lub możliwa jest separacja danych od modelu. Jest to korzystne, zwłaszcza przy tworzeniu i rozwiązywaniu bardzo dużych i skomplikowanych problemów optymalizacyjnych.

W programowaniu AMPL w tworzeniu i rozwiązywaniu modeli optymalizacyjnych używanych jest kilka podstawowych zwrotów [7]:

- set-deklaracje zbiorów,

- param - deklaracje parametrów modelu, 
- $v a r$ - deklaracje zmiennych decyzyjnych modelu,

- minimize, maximize - określenie rodzaju funkcji celu,

- subject to - ograniczenia modelu,

- solve - polecenie rozwiązania modelu,

- display - polecenie wydruku wyników (optymalnej wartości funkcji celu i optymalnych wartości zmiennych decyzyjnych).

Uproszczony sposób funkcjonowania systemu AMPL pokazano na rysun$\mathrm{ku} 2$. W pierwszym etapie tworzenia modelu przy pomocy zestawu poleceń, które tworzą język modelowania AMPL zapisywany jest plik całego modelu. Przy bardzo rozbudowanych zadaniach możliwe jest zapisanie oddzielnie pliku modelu i pliku danych, co ułatwia prowadzenie badań i zmianę poszczególnych składowych modelu. Następnie, po wczytaniu tych plików przez program następuje sprawdzenie poprawności zapisu oraz transformacja modelu i danych do formy pośredniej, którą odczytuje solver. System modelowania AMPL współpracuje z wieloma różnymi solverami, co umożliwia rozwiązywanie różnego rodzaju zadań optymalizacyjnych. Zadaniem solvera jest znalezienie optymalnego rozwiązania w ramach analizowanego problemu.

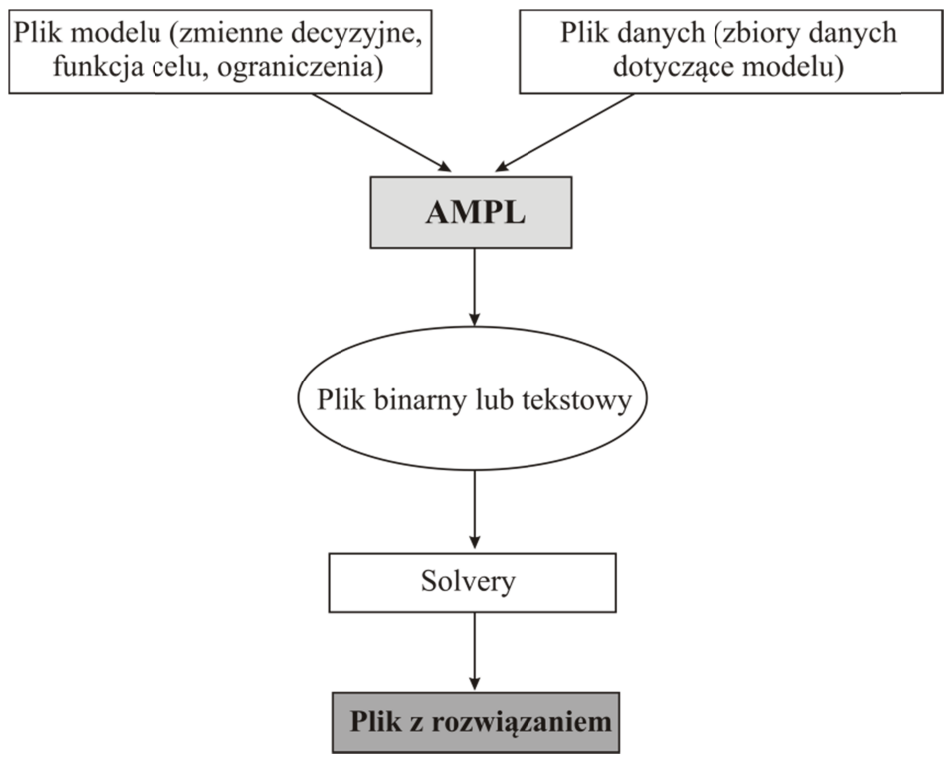

Rys. 2. Struktura systemu AMPL (na podstawie: [10])

Fig. 2. Structure of the AMPL (based on:[10])

Kolejnym etapem badań będzie przeprowadzenie szeregu analiz na zaimplementowanym modelu optymalizacyjnym zbiornika rurowego. W badaniach tych zamierza się określić wpływ wartości parametrów modelu optymalizacyjnego na poszukiwane wartości parametrów projektowych zbiornika. Jest to 
szczególnie istotne, gdyż parametry projektowe determinują całkowite koszty $L C C$ zbiornika i mogą wpływać decydująco na wybór rozwiązania optymalnego.

\section{Podsumowanie}

Opracowany model optymalizacyjny zbiornika rurowego, w którym uwzględniono wiele czynników wpływających na całkowite koszty jego budowy i funkcjonowania, jest praktycznym i uniwersalnym narzędziem umożliwiającym jego wykorzystanie w rozwiązywaniu rzeczywistych zadań inwestycyjnych. Model ten pozwoli na przeprowadzenie szczegółowych badań, których celem będzie określenie wpływu wybranych parametrów modelu na wartość kosztów LCC analizowanego zbiornika rurowego. Ważnym aspektem badań będzie zastosowanie sformułowanego modelu optymalizacyjnego w warunkach rzeczywistej zlewni miejskiej.

Przedstawiony model stanowi kontynuację badań opisanych w pracy [17]. Sformułowane w niej modele optymalizacyjne wybranych układów hydraulicznych zbiorników grawitacyjno-pompowych wraz z opisanym w tym artykule modelem zbiornika rurowego stanowią główny element algorytmu wyboru optymalnego rozwiązania zbiornika retencyjnego. $\mathrm{Z}$ uwagi na dużą kapitałochłonność inwestycji związanych z modernizacją i rozbudową systemów kanalizacyjnych opracowane modele mogą mieć strategiczne znaczenie dla projektantów i inwestorów w procesie podejmowania decyzji. Natomiast wyniki badań przeprowadzone na tych modelach mogą spowodować uzyskanie znacznych oszczędności w funduszach wydatkowanych na inwestycje komunalne.

\section{Literatura}

[1] Barringer H.P., Weber D.: Life Cycle Cost Tutorial. Fifth International Conference on Process Plant Reliability, Houston, Texas, October 2-4, 1996.

[2] Boomgaard M.E., Langeveld J.G., Clemens F.: Wastewater system optimization using genetic algorithms. World Water Congress, 2001.

[3] Brand N., Ostfeld A.: Optimal design of regional wastewater pipelines and treatment plant systems. Water Environ Res., vol. 83, no 1, 2011.

[4] Chmielowski W.: Zastosowanie optymalizacji w gospodarce wodnej. Wydawnictwo Politechniki Krakowskiej, Kraków 2005.

[5] Dajani J., Hasit Y.: Capital cost minimization of drainage networks. Journal of the Environmental Engineering Division, No. 2, 1974.

[6] Dziopak J.: Analiza teoretyczna i modelowanie wielokomorowych zbiorników kanalizacyjnych. Wydawnictwo Politechniki Krakowskiej, Kraków 1992.

[7] Fourer R., Gay D., Kernighan B.: A Modeling Language for Mathematical Programming. International Thomson Publishing, USA, 2002.

[8] Gutenbaum J.: Modelowanie matematyczne systemów. Akademicka Oficyna Wydawnicza EXIT, Warszawa 2003. 
[9] Holland M.: Computer models of wastewater collection systems. Harvard Water Resources Group, Cambridge, 1966.

[10] Holms D.: AMPL at the University of Michigan, 1995.

[11] Hong T., Han S., Lee S.: Simulation-based determination of optimal life-cycle cost for FRP bridge deck panels. Automation and Constructions, no. 16, 2007.

[12] Liebman J.: A heuristic aid for the design of sewer networks. Journal of the Sanitary Engineering Division, No 4, 1967.

[13] Kuliczkowski A.: Optymalizacja kolektorów kanalizacyjnych przebudowywanych w warunkach miejskich. Monografia, nr 12, Politechnika Wrocławska, 1988.

[14] Madryas C.: Optymalizacja projektowania sieci infrastruktury technicznej uzbrojenia podziemnego z uwzględnieniem warunków eksploatacji. Rozprawa doktorska, Politechnika Wrocławska, 1981.

[15] Sowiński M.: Projektowanie sieci i urządzeń kanalizacyjnych. Wydawnictwo Politechniki Poznańskiej, Poznań, 1986.

[16] Stec A.: Model kosztowy retencyjnego zbiornika rurowego. Czasopismo Inżynierii Lądowej, Środowiska i Architektury Politechniki Rzeszowskiej, z. 63, (1/16), styczeń-marzec 2016.

[17] Stec A.: Optymalizacja innowacyjnych zbiorników w kanalizacji ogólnospławnej. Rozprawa doktorska. Akademia Górniczo-Hutnicza w Krakowie, Kraków 2013.

[18] Stec A.: Optimization of the hydraulic system of the storage reservoir hydraulically unloading the sewage network. Ecological Chemistry and Engineering S, Vol. 21, No. 2, 2014, s. 215-228.

[19] Wartalski J.: Optymalizacja wybranych parametrów kolektorów zbiorczych w układach sieciowych systemów usuwania ścieków. Praca doktorska, Politechnika Wrocławska, 1983.

\section{OPTIMIZATION MODEL OF THE PIPE STORAGE RESERVOIR}

\section{S u m m a r y}

In this paper the formulated optimization model of the pipe tank was presented, which is a continuation of research described in the article [16]. Life Cycle Cost model (LCC) of the this tank was transformed into an optimization model, which sets the objective function as a minimum LCC cost. The application of this criterion in investment decision making process allows to make the correct choice in financial terms, as LCC methodology allows to take into account not only the initial investment, but also the operational costs incurred throughout the entire operation of the object. The model optimization was implemented in a programming language AMPL (A Mathematical Programming Language).

In the formulated model the decision variables which are geometrical parameters of the reservoir, such as the length and diameter of the tank and the cavity of the drainage channel from the reservoir were determined. Also the constraints of the optimization model were defined. First of them results from the retention capacity of the tank calculated at the stage of determining the input data for which the tank is designed. Next constraints concern land, which is available for the construction of the reservoir and the constraints of determining a minimum acceptable cavity of the drainage channel from the tank. While, the optimization model parameters are a set of data that were used to write the objective function, and whose values are known. 
Keywords: pipe tanks, storage reservoirs, Life Cycle Cost, optimization

DOI: $10.7862 / \mathrm{rb} .2016 .177$

Przestano do redakcji: $01.05 .2016 r$.

Przyjęto do druku: 28.06.2016 r. 